\title{
Varying Cecal Bacterial Loads Influences Colitis and Gastritis in HLA-B27 Transgenic Rats
}

\author{
HEIKO C. RATH, ${ }^{*}, \ddagger$ JACK S. IKEDA, ${ }^{\S}$ HANS-J ÖRG LINDE,॥ JÜRGEN SCHÖLMERICH, ${ }^{\ddagger}$ \\ KENNETH H. WILSON, ${ }^{\S}$ and R. BALFOUR SARTOR* \\ * Center for GI Biology and Disease, University of North Carolina, Chapel Hill, North Carolina; §Department of Infectious Diseases, VA Medical \\ Center, Duke University, Durham, North Carolina; and ₹Department of Internal Medicine I and IInstitute of Medical Microbiology and Hygiene, \\ University of Regensburg, Germany
}

Background \& Aims: Recent data support an important role of resident luminal bacteria in experimental colitis. We determined how altered cecal bacterial loads influence colitis and gastritis. Methods: A cecal self-filling blind loop (SFBL) was created or the cecum was excluded from the fecal stream in specific pathogenfree HLA-B27 transgenic (TG) rats with early colitis and in nontransgenic (nonTG) littermates; controls underwent sham operation (SHAM). Luminal bacterial concentrations were determined by culture and counting chamber. Results: TG rats with SFBL had more severe cecal inflammation and leukocytosis than TG SHAM controls. TG excluded rats with low cecal bacterial loads had no cecal inflammation and less colitis and gastritis than SHAM controls, despite having normal distal colonic and gastric bacterial concentrations. Metronidazole attenuated cecal inflammation and eliminated Bacteroides in SFBL TG rats. NonTG SFBL rats had mild cecal inflammation and no gastritis and colitis. The ratio of total anaerobic to aerobic bacteria was 1000 -fold greater in SFBL than in SHAM rats, with a 10,000-fold increased ratio of Bacteroides spp. to aerobes. Conclusions: The luminal bacterial load and composition determines the activity of cecal inflammation in genetically susceptible hosts. Lowering cecal bacterial concentrations can diminish inflammation in remote organs.

E xtensive data support an important role for normal luminal bacteria in inflammatory bowel disease, especially Crohn's disease and experimental enterocolitis. $^{1-3}$ Resident bacteria have been implicated in the pathogenesis of indomethacin-, ${ }^{4}$ carrageenan- ${ }^{5}$ and dextran sulfate sodium-induced ${ }^{6}$ intestinal inflammation, as well as spontaneous colitis in interleukin (IL)- $2^{-1-, 7}$ IL-10-I-, 8 CD 45RB ${ }^{\text {high }}$ reconstituted severe combined immunodeficient (SCID) mice, ${ }^{9}$ and $\mathrm{C} 3 \mathrm{H} / \mathrm{H}$ eJ Bir mice. ${ }^{10,11}$ In a recent study we showed the essential influence of resident bacteria on the spontaneous colitis and gastritis in HLA-B27/ $\beta 2$ microglobulin transgenic (TG) Fischer rats. ${ }^{12}$ The onset of spontaneous colitis and gastritis in TG rats normally begins at 2 months of age with a $100 \%$ incidence of nonbloody diarrhea by 3-4 months. ${ }^{13,14}$ In a sterile environment these animals do not develop colitis, gastritis, or arthritis. ${ }^{12,15} \mathrm{H}$ owever, when germfree rats were transferred into a specific pathogen-free (SPF) environment, all TG rats had histological and biochemical evidence of active colitis and gastritis after 4 weeks, al though diarrhea was not evident at this time. ${ }^{12}$

Additional data show that altering bacterial populations influences the degree of intestinal and extraintestinal inflammation. Decreasing luminal bacterial concentrations, especially of anaerobic bacteria, can be beneficial in both clinical and experimental enterocolitis. Crohn's colitis and il eocolitis respond to several antibiotics including metronidazole, ${ }^{16}$ which is sel ectively active against anaerobic bacteria. M etronidazole al so attenuates chronic experimental intestinal inflammation in the indomethacin and carrageenan model $s^{4,17}$ and in HLA-B27 TG rats. ${ }^{18}$ Bowel rest, leading to long-term reduction of luminal bacteria, is used to treat severe Crohn's disease. ${ }^{19-21} \mathrm{H}$ owever, anaerobic bacterial overgrowth in bypassed jejunoileal segments for morbid obesity leads to systemic inflammation. ${ }^{22}$ Experimental small intestinal anaerobic bacterial overgrowth in a jejunal self-filling blind loop (SFBL) can induce hepatobiliary inflammation and reactivate quiescent arthritis in genetically susceptible Lewis rats. ${ }^{23,24}$ In both human and rat bacterial overgrowth models, broad-spectrum antibiotics or metronidazole treat systemic manifestations. ${ }^{23,25-27}$ These results convincingly show that anaerobic bacteria play an

\footnotetext{
Abbreviations used in this paper: $B B E$, Bacteroides bile esculin; $\mathrm{BHI}$, brain heart infusion; EX, excluded from the fecal stream; LPS, lipopolysaccharide; nonTG, nontransgenic; PARS, prereduced anaerobically sterilized; PG-PS, peptidoglycan-polysaccharide; SCID, severe combined immunodeficiency disease; SHAM, sham-operated; SFBL, self-filling blind loop; SPF, specific pathogen free; TCR, T-cell receptor; TG, transgenic; WBC, white blood cell (count). (C) 1999 by the American Gastroenterological Association 0016-5085/99/\$10.00
} 
important role in induction of colitis and extraintestinal manifestations in genetically susceptible hosts. Our recent data support this hypothesis and show that all bacteria do not have equal abilities to induce gastrointestinal inflammation. G notobiotic B27 TG rats, colonized with 6 different obligate and facultative anaerobic bacteria including Streptococaus fa eci um, Streptococcus avi um, P eptostreptococaus productus, E scherichia col i, E ubacterium contortum, and $B$ acteroides vulgatus developed much more active colitis and gastritis than littermates colonized with the same bacteria without $B$. vul gatus. ${ }^{12}$

This study shows how alterations in the autologous cecal bacterial composition and load influence the degree of gastrointestinal inflammation in HLA-B27 TG rats, without using antibiotics or selected heterologous bacteria. Attention was focused on B acteroides spp. because our previous observations in gnotobiotic rats showed a dominant role for these species. ${ }^{12}$

\section{Materials and Methods}

\section{Animals}

A colony of HLA-B27 TG rats and nontransgenic (nonTG) littermates ${ }^{13}$ originally obtained from $\mathrm{Dr}$. J oel $\mathrm{D}$. Taurog (Southwestern M edical School, Dallas, TX) was derived into a sterile environment, populated with SPF bacteria, then housed and maintained in an SPF environment. ${ }^{12}$

\section{Experimental Design}

TG rats $(\mathrm{N}=21)$ raised in an SPF environment were divided into 3 groups at 2 months of age, when colitis first becomes evident. In one group a cecal SFBL was created as described later, in the second group the cecum was excluded from the fecal stream (EX), and the third group was sham operated (SH AM ). N onTG littermates $(n=11)$ were SH AM or SFBL operated and served as negative controls. All rats were monitored weekly for clinical evidence of diarrhea and arthritis. One month after surgery, at the age of 3 months, all rats were killed by $\mathrm{CO}_{2}$ asphyxiation. Anticoagulated cardiac blood was obtained for white blood cell (W BC) counts. The cecum and col on wereinspected grossly in a blinded fashion for evidence of intestinal thickness and scored on a validated scale ranging from 0 to $4^{+}$as previously described. ${ }^{12}$ The cecum, stomach, and right colon were fixed in $10 \%$ buffered formalin for histological evaluations. Tissues from the transverse col on were snap-frozen in isopentane for protein assays.

In a separate experiment, we treated TG SFBL rats with metronidazole, $40 \mathrm{mg} \cdot \mathrm{kg}^{-1} \cdot$ day $^{-1}$, in drinking water. Treatment was begun at the age of 8 weeks, and surgery was performed at 10 weeks. M etronidazole-treated rats $(n=4)$ and water controls $(n=4)$ were killed at 14 weeks of age. Cecal tissue was removed for histology.

All studies were performed with the approval of the University of $\mathrm{N}$ orth Carolina A nimal Care and U se Committee.

\section{Creation of a Cecal SFBL}

Cecal SFBLs were created in TG rats $(n=8)$ and nonT $G$ littermates $(n=6)$ at 2 months of age. A nesthesia was induced using $40 \mathrm{mg} / \mathrm{kg}$ intramuscular ketamine and 0.75 $\mathrm{mg} / \mathrm{kg}$ acepromazine. After a midline incision, the cecum was ligated at the cecal-colonic junction using a 4.0 silk suture (Figure 1). Continuity of the fecal stream was accomplished by a side-to-side anastomosis between the terminal ileum and the transverse colon, using 6.0 Vicryl sutures (Ethicon Inc., Sommerville, N J). SH AM operation (TG, N = 5; nonTG, $N=$ 5 ) included a laparotomy and external manipulation of the cecum, but no ligation or anastomosis.

\section{Exclusion of the Cecum}

Surgery was performed on TG rats $(n=8)$ at 2 months of age. After anesthesia and midline incision the cecum was separated from the right colon and terminal ileum (Figure 1). The section of the terminal ileum connected to the cecum was ligated using a 4.0 silk suture. A colostomy was performed using the col onic end of the cecum. The transected right col on was ligated and an end-to-side anastomosis with the terminal ileum was created using 6.0 Vicryl sutures.

\section{Determination of Bacterial Concentrations}

The cecum, colon, jejunum, ileum, and stomach of TG and nonTG rats (SFBL, EX, and SHAM) were removed and

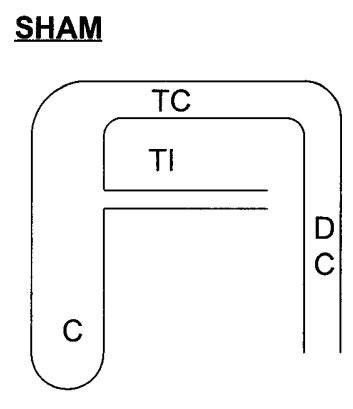

SFBL
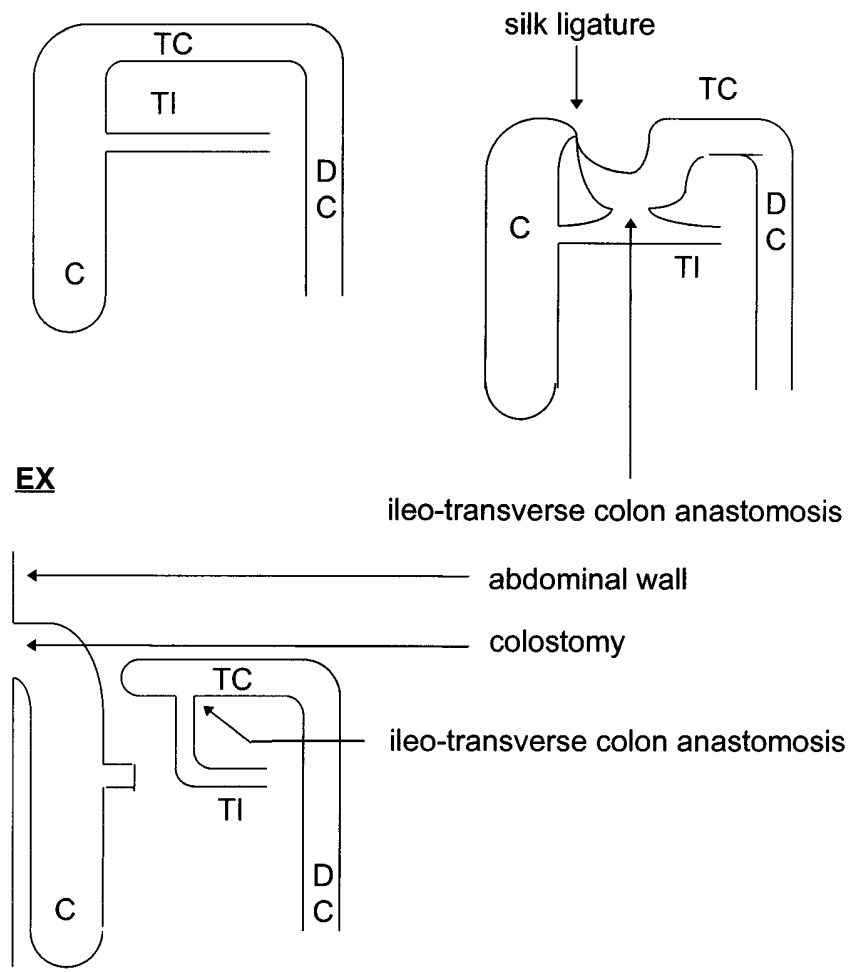

Figure 1. Surgical procedures to create an SFBL and exclusion of the cecum with a colostomy (EX). Surgical procedures were performed on 2-month-old TG Fischer rats and nonTG littermates. C, cecum; TI, terminal ileum; TC, transverse colon; DC, descending colon. 
immediately placed into an anaerobic isolator. O ne milliliter of cecal contents was taken, weighed, and serially diluted in phosphate-buffered saline or prereduced thioglycolate broth. From every 10 -fold dilution, $100 \mu \mathrm{L}$ were plated on modified Bryant's medium 10 (M M 10) agar or prereduced anaerobically sterilized (PRAS) agar plates in an anaerobic $5 \% \mathrm{CO}_{2}, 10 \% \mathrm{H}_{2}$, and $85 \% \mathrm{~N}_{2}$ atmosphere. A erobic culture was performed using enriched brain heart infusion (BHI) agar or blood agar plates. Colonies were counted after 2 (aerobic) and 6 (anaerobic) days of incubation at $37^{\circ} \mathrm{C}$. B acteroides spp. were selectively grown on $B$ acteroides Bile Esculin (BBE) Agar under anaerobic conditions. Morphology was determined by Gram stain. Total bacterial concentrations were determined on serial dilutions with phase-contrast microscopy using a Petroff- $\mathrm{H}$ auser counting chamber. Identification of presumed B acteroides spp. was performed according to standard procedures. ${ }^{28}$ Results were normal ized for stool dry weights.

\section{Histology}

Tissues were prepared as previously described. ${ }^{12} \mathrm{~A}$ val idated histological inflammatory score ranging from 0 to $4^{+}$ was used for blinded eval uation of colonic and gastric inflammation. ${ }^{12}$

\section{Rat IL-1 $\beta$ ELISA}

We measured IL- $\beta$ protein concentrations in the cecal tissue by enzyme-linked immunosorbent assay (ELISA) as previously described, ${ }^{12}$ using antibodies that were provided by Dr. S. Poole, National Institute of Biological Standards and Controls, Hertfordshire, England.

\section{Statistical Analysis}

Statistics were performed using the analysis of variance and the Student $t$ test for comparison between the groups and the $\chi^{2}$ test for nominal data. Significance was considered to be $P<0.05$. All data are presented as mean \pm SEM.

\section{Results}

\section{Clinical Features}

One hundred percent of the TG SFBL rats had diarrhea 3-4 weeks after surgery compared with $0 \%$ of the SH AM and EX groups ( $P<0.0005)$. There were no differences in weight gain in the various groups. One TG rat with SFBL developed active arthritis, but no arthritis was observed in the SH AM and EX groups. N onTG rats had no evidence of diarrhea or arthritis.

\section{Cecal Inflammation}

The blinded gross gut score of the cecum (Figure 2) was significantly increased in the TG SFBL compared with TG SHAM rats $(3.6 \pm 0.1$ vs. $1.6 \pm 0.2 ; P<$ 0.0001 ). The predominant visible abnormal ity was thickening of the large intestine, which was more evident in the cecum than in the colon. There were no macroscopic

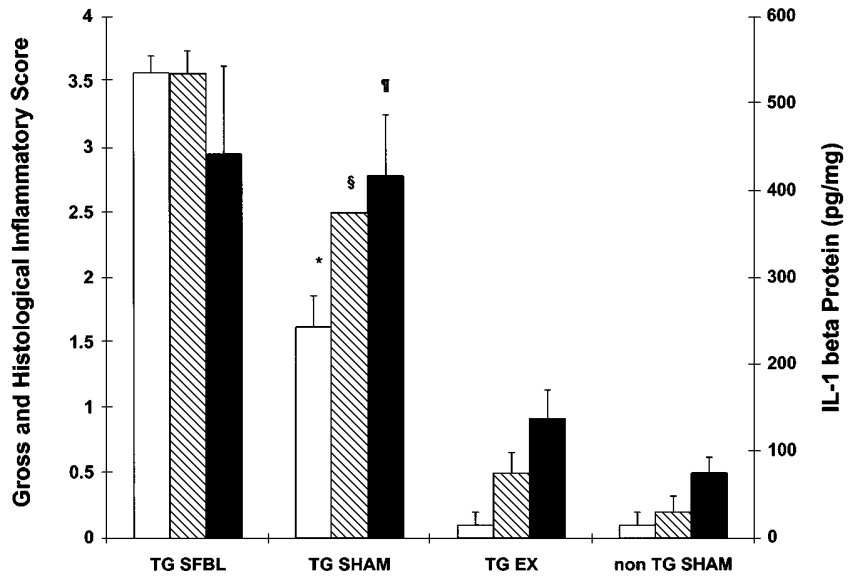

Figure 2. Quantitation of cecal inflammation in HLA-B27/ $\beta 2$ microglobulin TG rats exposed to variable bacterial loads. Blinded gross ( $\square$ ) and histological $(\mathbb{Q})$ evaluations showed significantly increas ed inflammation in TG rats with SFBL $(\mathrm{N}=8)$ and significantly decreased inflammation in TG EX rats $(\mathrm{N}=8)$ compared with TG SHAM controls $(N=5)$. There was no difference between TG EX and nonTG SHAM

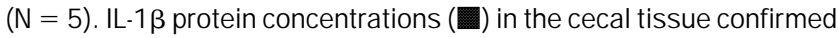
decreased inflammation in TG EX vs. TG SHAM, but showed no difference between TG SFBL and TG SHAM. $* P<0.0001$ vs. all other groups. $\S P<0.002$ vs. TG SFBL and $P<0.0001$ vs. TG EX and nonTG SHAM. $" P<0.007$ vs. TG EX and nonTG SHAM.

signs of inflammation in the TG EX and nonTG SH AM groups $(0.1 \pm 0.1$ for both; $P<0.0001$ vs. TG SH AM $)$.

$\mathrm{H}$ istological inflammation in the lamina propria of the cecum of TG SH AM rats (Figure $3 \mathrm{~A}$ ) was characterized by diffuse infiltration of predominantly mononuclear cells and scattered eosinophils but few neutrophils, thickening of the mucosa with crypt hyperplasia, few scattered crypt abscesses, and rare superficial ulcerations. Inflammation was confined to the mucosa. Mucosal inflammation was increased in TG SFBL rats and extended to the submucosa compared with TG SHAM controls (Figure $3 C$ and $D$ ). Seventy-five percent of TG SFBL rats had submucosal inflammation vs. $0 \%$ of TG SH AM rats $(P<0.01)$. M ore aggressive cecal inflamma tion in SFBL TG rats was confirmed by blinded histol ogical inflammatory scores ( $3.6 \pm 0.2$ vs. $2.5 \pm 0 ; \mathrm{P}<$ 0.005 ; Figure 2). There was al most no evidence of cecal inflammation in TG EX rats (Figure 3B ), as confirmed by the lack of difference in histological scores of TG EX and nonTG SH AM rats $(0.5 \pm 0.2$ vs. $0.2 \pm 0.1$; both $P<$ 0.0001 vs. TG SH AM; Figure 2).

IL-1 $\beta$ protein concentrations in the cecal tissue (Figure 2) of TG EX were significantly reduced compared with TG SH AM $(138.0 \pm 32.9$ vs. $417.9 \pm 69.5 \mathrm{ng} / \mathrm{g}$ tissue; $P<0.01)$. H owever, there were no differences evident between TG SHAM and SFBL (442.9 \pm 100.5$)$ or between TG EX and nonTG SHAM (75.3 \pm 17.8) groups.

N onTG SFBL rats had mild-to-moderate grossly de- 

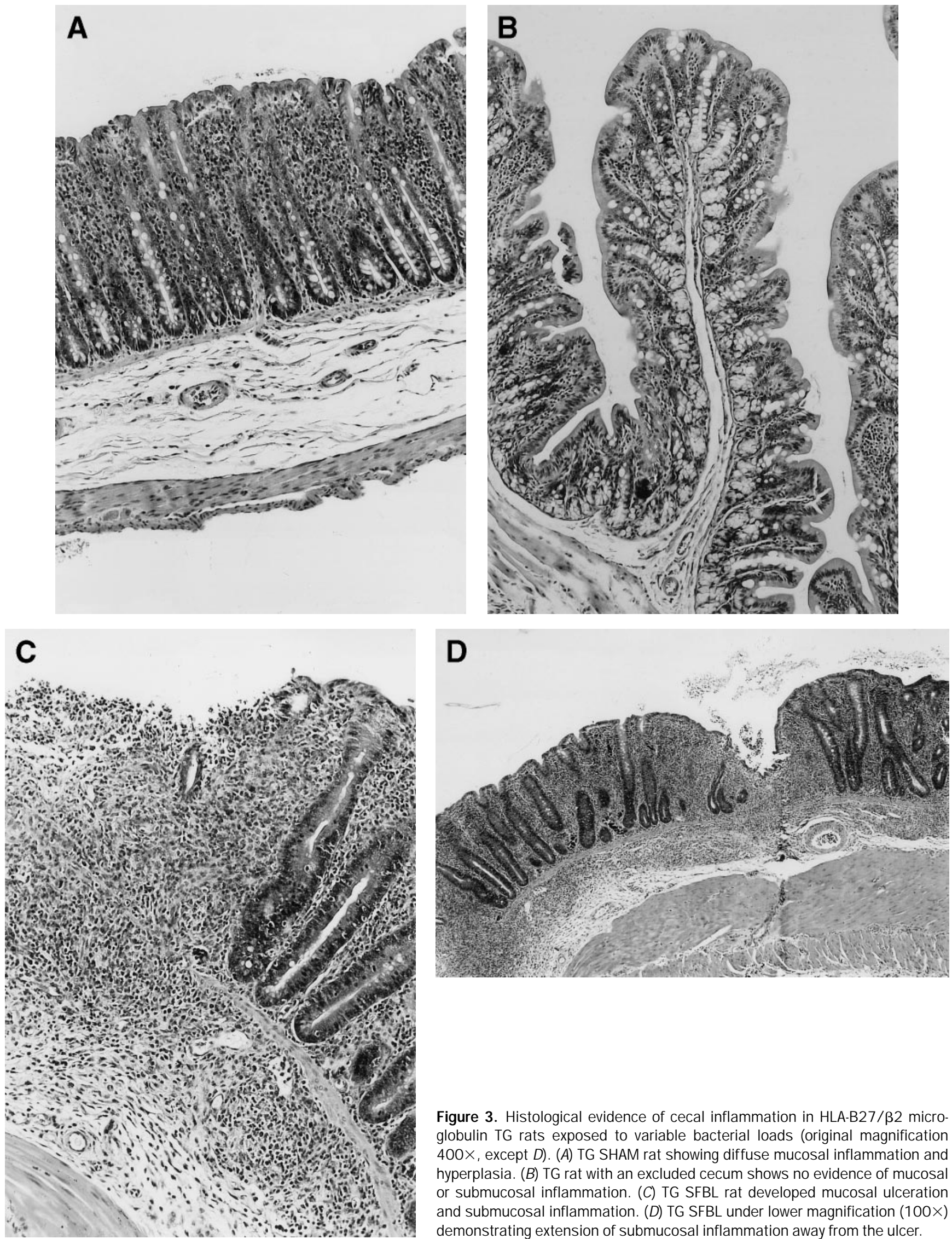

Figure 3. Histological evidence of cecal inflammation in HLA-B27/ $\beta 2$ microglobulin TG rats exposed to variable bacterial loads (original magnification $400 \times$, except $D$ ). (A) TG SHAM rat showing diffuse mucosal inflammation and hyperplasia. (B) TG rat with an excluded cecum shows no evidence of mucosal or submucosal inflammation. (C) TG SFBL rat developed mucosal ulceration and submucosal inflammation. (D) TG SFBL under lower magnification $(100 \times)$ demonstrating extension of submucosal inflammation away from the ulcer. 
Table 1. Bacterial Concentrations From Various Regions of TG and NonTG Rat Gastrointestinal Tract

\begin{tabular}{|c|c|c|c|c|c|}
\hline & Stomach & Jejunum & Ileum & Cecum & Colon \\
\hline Total count (organism/ mL) & $0.5-1.6 \times 10^{12}$ & $3-8 \times 10^{11}$ & $2-3 \times 10^{11}$ & $3-4 \times 10^{12}$ & $3 \times 10^{12}$ \\
\hline Anaerobic culture (CFU/ mL) & $4-6 \times 10^{9}$ & $3-6 \times 10^{8}$ & $3-5 \times 10^{9}$ & $0.2-2 \times 10^{10}$ & $0.5-1 \times 10^{10}$ \\
\hline Aerobic culture (CFU/ mL) & $0.4-2.5 \times 10^{9}$ & $1-5 \times 10^{7}$ & $3-8 \times 10^{8}$ & $0.2-2.7 \times 10^{9}$ & $0.4-3.8 \times 10^{9}$ \\
\hline Bacteroides spp. (CFU/ mL) & $0-1 \times 10^{5}$ & $2-4 \times 10^{2}$ & $0.1-1 \times 10^{5}$ & $0.4-2 \times 10^{8}$ & $1-3 \times 10^{8}$ \\
\hline
\end{tabular}

NOTE. Results are expressed in organisms/ $\mathrm{mL}$ luminal contents for the total count and in CFU/ $\mathrm{mL}$ for the cultures. After serial dilutions of the luminal contents, the total number of microscopically visible bacteria, colonies grown on MM10 agar under anaerobic conditions, colonies grown on $\mathrm{BHI}$ enriched agar under aerobic conditions, and colonies grown on BBE agar under anaerobic conditions, which permits selective growth of Bacteroides spp., were counted. Results are expressed as the range of 3 experiments.

tectable cecal thickening (gross score, $1.3 \pm 0.4$ ) but had only very mild inflammation by histological criteria $(0.6 \pm 0.1$, nonsignificant vs. TG EX and $\mathrm{P}<0.02$ vs. nonT G SH AM ). By histology this thickening was caused by muscular hypertrophy and mild submucosal edema. IL-1 $\beta$ protein concentrations were not elevated in the nonTG SFBL group $(83.9 \pm 22.2)$, confirming the lack of active inflammation.

These results show a consistent increase in cecal inflammation in TG rats with a SFBL and a virtual absence of inflammation in the excluded cecum by gross, histological, and biochemical parameters.

TG SFBL rats treated with metronidazole had significantly less cecal inflammation than water controls, as shown by blinded histology score $(2.4 \pm 0.1$ vs. $3.5 \pm$ $0.4 ; P<0.05)$.

\section{Colitis}

There was no gross evidence of inflammation in the colon in TG EX and nonTG SH AM rats $(0.0 \pm 0.0$ for both; $P<0.005$ vs. TG SHAM) by blinded examination. TG SFBL rats had slightly more colonic inflammation than TG SH AM $(2.0 \pm 0.2$ vs. $1.1 \pm 0.3$; $P<0.05)$. Histological evidence of colitis was also reduced in the TG EX compared with TG SHAM (1.1 \pm 0.2 vs. $1.8 \pm 0.1 ; P<0.05)$, but was significantly higher than nonTG SHAM controls $(0.1 \pm 0.1 ; P<0.01)$. There was no significant difference between histological inflammatory scores in the TG SFBL $(2.2 \pm 0.2)$ and TG SH AM groups. Grossly and histologically there was no colitis in the nonTG SFBL group $(0.2 \pm 0.1$ and $0.3 \pm$ $0.2)$, respectively. These results indicate that alterations in cecal bacterial loads can affect inflammation in the distal colon.

\section{Gastritis}

Antral gastritis, with mucosal thickening and mononuclear cell infiltration predominantly in the basal two thirds of the crypts, was a consistent histological feature in TG SHAM and SFBL rats (histological score, $2.6 \pm 0.1$ vs. $2.5 \pm 0.1 ; N$ S). Surprisingly, gastritis was significantly decreased in the TG EX group $(0.4 \pm 0.2$;
$P<0.0005)$ and totally absent in some of these animals. There was no gastritis in nonTG SFBL animals $(0.1 \pm$ $0.1)$.

\section{Hematologic Features}

TG SFBL rats had higher peripheral W $B C$ counts $(21.6 \pm 1.1$ vs. $15.7 \pm 2.1 ; P<0.02)$ than TG SH AM, whereas TG EX had al most normal W BC counts (8.8 \pm 1.0; $P<0.01$ vs. TG SH AM). N onTG SFBL rats had slightly elevated $W B C$ counts $(12.0 \pm 1.3 ; P<0.03$ vs. TG EX and nonTG SHAM; NS vs. TG SHAM). There was no difference in hemoglobin and hematocrit values between the groups (data not shown).

\section{Microbial Results}

In SH A M rats (Table 1) the total, microscopically visible number of bacteria per milliliter luminal contents in the stomach, jejunum, and ileum was 1 log less than in the cecum and colon. A erobically cultivable bacteria had the lowest concentrations in the jejunum and highest concentrations in the cecum and colon. Our results show a luxurious presence of bacteria in the rat stomach. Bacteria in the stomach and jejunum were predominantly gram-positive rods and coccobacilli; in addition, sporeforming rods were present in the ileum. The microscopic picture of the cecal bacteria was quite complex, yet similar to the colon, dominated by gram-positive bacilli and sporeforming rods with less frequent gram-negative bacilli. Using sel ective culture media, concentrations of presumed Bacteroides spp. were 3-6 logs higher in the cecum and colon compared with the jejunum and ileum. One of 3 rats had no detectable $\left(<10^{2} / \mathrm{mL}\right)$ B acteroides spp. in the stomach.

In TG and N T rats the concentrations of total visible bacteria in the cecal contents were equal between the SFBL and SH AM groups (Table 2). H owever, the number of bacteria recovered under anaerobic growth conditions (obligate and facultative anaerobes) was significantly increased in the SFBL group, whereas bacteria recovered under aerobic growth conditions (aerobes and facultative anaerobes) in the SFBL group were significantly decreased compared with the SH AM group. Thus, the ratio 
Table 2. Cecal Bacterial Concentrations

\begin{tabular}{|c|c|c|c|c|c|c|}
\hline & \multicolumn{3}{|c|}{ NonTG $(\mathrm{N}=6)$} & \multicolumn{3}{|c|}{$\mathrm{TG}(\mathrm{N}=1-2)$} \\
\hline & SFBL & SHAM & EX & SFBL & SHAM & EX \\
\hline Total & $2-6 \times 10^{12}$ & $3-6 \times 10^{12}$ & $2-4 \times 10^{10 a}$ & $2-3 \times 10^{12}$ & $2-3 \times 10^{12}$ & $2 \times 10^{10}$ \\
\hline Anaerobic & $2( \pm 0.6) \times 10^{10 a}$ & $4( \pm 1) \times 10^{9}$ & $2( \pm 1) \times 10^{6}$ & $2-4 \times 10^{10}$ & $3-4 \times 10^{9}$ & $5 \times 10^{8}$ \\
\hline Aerobic & $7( \pm 3) \times 10^{6} a$ & $9( \pm 4) \times 10^{8}$ & $2( \pm 0.4) \times 10^{6}$ & $2-6 \times 10^{7}$ & $2-3 \times 10^{9}$ & $4 \times 10^{7}$ \\
\hline Bacteroides spp. & $9( \pm 4) \times 10^{9 a}$ & $2( \pm 0.8) \times 10^{7}$ & $4( \pm 0.4) \times 10^{5}$ & $2 \times 10^{9}$ & $4 \times 10^{7}$ & ND \\
\hline Ratio anaerobic/ aerobic & $2846 \pm 2186^{a}$ & $5 \pm 2.5$ & $1 \pm 0.3$ & $333-2000$ & $1-2$ & 13 \\
\hline Ratio Bacteroides spp./ aerobic & $1703 \pm 815^{a}$ & $0.02 \pm 0.007$ & $0.2 \pm 0.1$ & $33-100$ & $0.01-0.02$ & ND \\
\hline Cecal weight including contents & ND & ND & ND & $14.8 \mathrm{~g}$ & $4 \mathrm{~g}$ & $1.5 \mathrm{~g}$ \\
\hline
\end{tabular}

NOTE. Results are expressed in organisms/ $\mathrm{mL}$ luminal contents for the total count and in CFU/ $\mathrm{mL}$ for the cultures using the techniques described in Table 1. After serial dilutions in phosphate-buffered saline or prereduced thioglycolate, cecal contents were cultured anaerobically on MM10, PRAS, and BBE agar plates and aerobically on enriched BHI and blood agar plates. Results of trans genic and microscopic counts of nonTG rats are expressed as the range of 1-2 experiments. Culture results of nonTG rats $(n=6)$ are expressed as mean values.

ND, not done.

$a P<0.05$ Vs. nonTG SHAM.

of anaerobically cultured bacteria to aerobically grown organisms in the SFBL rats was al most 3 logs higher than that of the SH AM group. Similarly, the concentrations of isolates on the Bacteroides selective media were significantly higher in the SFBL rats compared with the SH AM group, and the ratio of cecal $B$ acteroides spp. to aerobically grown bacteria was almost 5 logs higher in the SFBL group (Table 2). The dominant $B$ acteroides spp. were $B$. fragilis and $B$. vulgatus, present in approximately equal frequencies, with no difference in the relative frequency of these strains in SFBL vs. SH AM rats. R ats from the T G EX group had 2-3 log decreased total and viable cecal bacterial concentrations and 2 log fewer $B$ acteroides spp. in the cecum compared with SHAM. In TG SFBL rats treated with metronidazole no Bacteroides spp. were detectable in cecal contents. Although total bacterial concentrations per milliliter cecal contents were similar between the SFBL and SH AM groups, the enlarged ceca of SFBL rats were considerably heavier (Table 2 ) because of increased luminal contents and the thickened cecal walls, leading to much higher bacterial loads in the SFBL ceca.

The total concentrations of bacteria in the stomach and colon were not different between the groups (SHAM, SFBL, EX; data not shown).

\section{Discussion}

These data emphasize the important role of luminal resident bacteria in the pathogenesis of spontaneous colitis in H LA-B27 transgenic rats by showing that the degree of local cecal inflammation depends on the luminal bacterial load and composition in this genetically susceptible host. In the excluded cecum both the bacterial concentration and total bacterial load are decreased, with a corresponding decrease in inflammation. H owever, al though the overall bacterial concentration is normal in the cecal blind loop, the total load of bacteria is increased, because of the higher volume of cecal contents, as manifested by cecal weight, and is associated with more aggressive mucosal and submucosal inflammation. $\mathrm{H}$ owever, cecal inflammation is not exclusively dependent on the bacterial load, because disease fails to develop in the blind loop of nonTG rats, showing a corequirement of host genetic susceptibility. These findings are consistent with previous observations in several different models. Lichtman et al. induced hepatobiliary inflammation and arthritis in genetically susceptible Lewis rats by creating small intestinal bacterial overgrowth with a jejunal SFBL ${ }^{23,24}$ and reported pouchitis in Lewis rats with an ileal pouch-rectal anastomosis. ${ }^{29}$ Each of these models were related to bacterial overgrowth of predominantly anaerobic bacteria, including Bacteroides spp., and responded to metronidazole treatment, which eliminated B acteroides spp. 23,25,29 Similarly, proximal diversion of the fecal stream by ileostomy induces remission in Crohn's disease, reduces steroid requirements, and prevents postoperative disease recurrence, but symptoms recur soon after reestablishing intestinal continuity $20,21,30$ or infusion of luminal contents. ${ }^{31}$

The ratio of anaerobic to aerobic bacteria and the concentration of Bacteroides spp. seem to be additional determinants of inflammation. Although the luminal concentration of cultivable anaerobic bacteria in SFBL rats was only slightly increased by 1 log, the number of aerobically grown bacteria was decreased by 2 logs. Therefore, the ratio of anaerobic (which includes obligate and facultative anaerobes) to facultative anaerobic bacteria was up to 1000 -fold higher in the SFBL vs. SH AM rats. The ratio of $B$ acteroides spp. to facultative anaerobic bacteria was increased to an even greater degree $(10,000-$ 100,000 -fold higher in the SFBL vs. SHAM group). $M$ oreover, concentrations of bacteria grown in $B$ acteroides 
selective media in the cecum and colon of the SH AM group were 5-6 logs higher than in the proximal small intestine. Although the selected BBE agar probably does not recover all $B$ acteroides and we were able to recover $1 \%$ or less of organisms observed by phase-contrast microscopy, an equal percentage of organisms should be recovered in all groups. Total bacterial concentrations were 2 logs lower in the colon of the EX group compared with SHAM rats. Anaerobic bacteria, especially Bacteroides spp., have been incriminated in the pathogenesis of Crohn's colitis and experimental colitis by earl ier studies. Fecal concentrations and serum antibodies to anaerobic bacteria, such as B acteroides, E ubacteria, and P eptostreptococcus, are increased in Crohn's disease. ${ }^{2,32-35}$ Furthermore, patients with Crohn's disease have increased mucosal antibodies against luminal bacteria, including B acteroides spp. ${ }^{36}$ M etronidazole, which is selectively active against anaerobic bacteria and which can chronically suppress Bacteroides spp., ${ }^{37}$ is effective in Crohn's colitis and ileocolitis, ${ }^{16}$ in spontaneous colitis in B27 TG rats, ${ }^{18}$ and in indomethacin-induced chronic intestinal inflammation ${ }^{4}$ and prevents hepatobiliary injury and arthritis associated with small bowel bacterial overgrowth in the jejunal SFBL model.23,25 In the jejunal SFBL model, metronidazole and tetracycline had very little effect on total bacterial concentrations but eliminated Bacteroides spp., whereas gentamycin and polymyxin B had no effect on $B$ acteroides concentrations and exhibited no protective benefit on inflammation. ${ }^{25}$ Similarly, we show that metronidazole attenuates local inflammation in the cecal SFBL model and eliminates detectable B acteroides spp. B . vulgatus has been incriminated in the pathogenesis of H LA-B27 TG rats ${ }^{12}$ and carrageenan-induced colitis in guinea pigs ${ }^{5}$ by reconstitution studies. In addition, Cong et al. ${ }^{11}$ documented $C D 4^{+} T$ cell responses to $B$. vulgatus in $\mathrm{C} 3 \mathrm{H} / \mathrm{HeJ}$ Bir mice. Furthermore, Garcia-La Fuente et al. ${ }^{38}$ recovered $B$. fragilis and $B$. uniformis from inflamed colonic walls after trinitrobenzene sulfonic acid treatment in rats and showed that anaerobes played a key role in transmural inflammation in this model. In the present study, we found $B$. vulgatus and $B$. fragilis to be the dominant B acteroides spp. Although B acteroides spp. appeared to be involved in cecal inflammation, other anaerobes and even aerobes contribute to the inflammatory response, because metronidazole eliminated de tectible $B$ acteroides spp. but did not completely eliminate cecal inflammation. H owever, anaerobic bacteria seem to play only a minor role in ulcerative colitis ${ }^{2}$ and antibiotics are not effective with the exception of ciprofloxacin. ${ }^{39}$ Although spontaneous colitis in H LA-B27 TG rats more cl osely resembles ulcerative colitis than Crohn's disease, the presence of focal mucosal ulcerations and transmural inflammation in the presence of increased bacterial loads following creation of an SFBL suggests a Crohn's-like pattern. Furthermore, the $\mathrm{TH}_{1}$ profile of cytokines in HLA-B27 TG rats ${ }^{12}$ more closely resembles Crohn's disease than ulcerative colitis. ${ }^{40}$

Gastritis is a common feature in several colitis model $5^{7,12,41}$ and is found in up to $60 \%$ of Crohn's disease patients after careful investigation. ${ }^{42}$ Surprisingly, gastritis in TG rats seems to be more dependent on cecal than gastric bacterial loads. EX and SHAM rats had equal bacterial concentrations in the stomach, yet gastritis was significantly reduced in the EX group and completely absent in some of these animals. We hypothesize that exposure to anaerobic bacteria, such as Bacteroides spp., increases mucosal uptake of bacterial components in the cecum, which contains large lymphoid aggregates. ${ }^{43}$ This uptake of bacteria and bacterial antigens stimulates mucosal lymphocytes, which then circulate and home to different mucosal sites, such as the colon and stomach, where in the rat the total bacterial load is higher than in the jejunum and ileum. This hypothesis is supported by observations that enterotoxins secreted by several $B$. fragilis spp. increases epithelial permeability and bacterial internalization by HT-29 enterocytes, ${ }^{44}$ small bowel bacterial overgrowth enhances mucosal uptake of the bacterial cell wall polymer peptidoglycan-polysaccharide (PG-PS), ${ }^{26}$ and the homing of mucosal lymphocytes in SCID mice is dependent on enteric bacteria. ${ }^{9}$ Furthermore, this concept is consistent with suppression of colitis in $T$ cell receptor (TCR)- $\alpha$ deficient mice by resection of the cecal tip ("appendix"), which contains a large lymphoid aggregate. ${ }^{43}$ Although our results agree in principle with those of Mizoguchi et al. ${ }^{43}$ in which early "appendectomy" prevented the onset of colitis in TCR - $\alpha$ knockout mice for up to 6 months, the present study includes several important new advances in knowledge. (1) The influence of the cecum on inflammation in the stomach, an even more remote organ than the colon, further supports the concept of local T-cell induction in the cecum followed by lymphocyte trafficking to remote sites. (2) Microbial assessments strongly implicate normal cecal luminal bacteria in the pathogenesis of local inflammation in the cecum and in remote organs such as the stomach, because the excluded cecum had 2 logs less of cecal bacteria but equal gastric bacteria compared with SH AM controls. In contrast, cecal overgrowth of anaerobic bacteria dramatically aggravates the local inflamma tion but does not influence gastritis. (3) A ppendectomy in the TCR- $\alpha$ knockout mice was performed at 3 weeks of age (before the onset of colitis) and prevented colitis for 6 months, ${ }^{43}$ whereas the exclusion of the cecum in B27 TG rats was performed at 2 months of age (after the onset 
of gastrointestinal inflammation) and therefore treated established colitis and gastritis. In contrast, appendectomy performed after 5 weeks of age did not prevent colitis in TCR $-\alpha$ mice. $^{43}$ of interest, luminal bacterial stimulation al so appears to influence colitis in TCR- $\alpha$ deficient mice as evidenced by development of an oligoclonal immune response to cecal bacteria ${ }^{45}$ and absence of colitis in a sterile environment. ${ }^{46}$

An alternative, but less likely, explanation of the remote inflammation is that cytokines and soluble inflammatory mediators secreted by the inflamed cecal mucosa cause antral mucosal injury. Therefore, in the absence of cecal inflammation, systemic cytokine concentrations could be lower than controls. The lack of enhanced gastritis with significantly more aggressive cecal inflammation with cecal bacterial overgrowth in SFBL TG rats makes this explanation less likely.

Systemic manifestations such as arthritis and leukocytosis, which were more pronounced in the SFBL group, are probably caused by increased mucosal absorption of proinflammatory bacterial products such as lipopolysaccharide (LPS) and PG-PS, or translocation of viable bacteria. $^{2}$ In the jejunal SFBL model small intestinal bacterial overgrowth causes hepatobiliary injury, ${ }^{24}$ reactivates quiescent arthritis in genetically susceptible Lewis rats, ${ }^{23}$ and leads to bacterial translocation into mesenteric lymph nodes ${ }^{24}$ and systemic absorption of LPS $^{47}$ and PG -PS. ${ }^{24,26}$ Furthermore, systemic endotoxemia occurs in trinitrobenzene sulfonic acid- and acetic acid-induced colitis, ${ }^{48,49}$ and correlates with disease activity in ulcerative colitis and Crohn's disease. ${ }^{50}$ It was somewhat surprising that arthritis occurred only in 1 of 8 TG rats with a cecal SFBL. There might be two explanations: (1) arthritis and hepatobiliary injury in the jejunal SFBL model was induced in genetically susceptible Lewis rats, ${ }^{23}$ whereas our TG rats are on the resistant Fischer background ${ }^{24}$; and (2) arthritis in B27 T G Fischer rats in our SPF environment is mild, inconsistent, and follows an undulating pattern with a very late onset. ${ }^{12}$ O ur rats were killed at 3 months of age corresponding with the earliest onset of arthritis in this model. ${ }^{14} \mathrm{~A}$ mild degree of leukocytosis is expected in B27 TG rats. ${ }^{12,13}$ The increased leukocytosis in the TG SFBL group is consistent with our previous observations that TG rats with a jejunal SFBL had higher WBC counts than TG rats without surgery. ${ }^{51}$

This study emphasizes the direct influence of the cecal anaerobic bacterial load, especially B acteroides spp., and the ratio of anaerobic to aerobic bacteria on local inflammation in the cecum, because the degree of inflammation correlates with levels of isolates on Baderoidessel ective medium and increased anaerobic/aerobic and B acteroi- des/aerobic ratios and cecal inflammation was attenuated by metronidazole, which dramatically decreased cecal B acteroides concentrations. M oreover, it shows that the cecal bacterial load influences remote inflammation in the distal colon, stomach, and bone marrow through as yet undefined mechanisms. These results have important therapeutic implications for human inflammatory bowel diseases that may extend past the established approaches of bowel rest and antibiotic therapy. Future studies should focus on more specific antimicrobial therapeutic protocols targeting anaerobic bacteriaand $B$ acteroides spp., on blockade of membrane receptors for PG -PS, LPS, and chemotactic peptides from anaerobes, on enhancing luminal growth of protectivebacteria competing for anaerobic niches, and on direct immunologic approaches targeting B acteroides antigens.

\section{References}

1. Sartor RB, Rath HC, Sellon RK. Microbial factors in chronic intestinal inflammation. Curr Opin Gastroenterol 1996;12:327333.

2. Sartor RB. Microbial factors in the pathogenesis of Crohn's disease, ulcerative colitis and experimental intestinal inflammation. In: Kirsner JB ed. Inflammatory bowel disease. 5th ed. Philadelphia: Saunders, 1999 (in press).

3. Sartor RB. The influence of normal microbial flora on the development of chronic mucosal inflammation. Res Immunol 1997;148: 567-576.

4. Yamada T, Deitch E, Specian RD, Perry MA, Sartor RB, Grisham $M B$. Mechanisms of acute and chronic intestinal inflammation induced by indomethacin. Inflammation 1993;17:641-662.

5. Onderdonk AB, Franklin ML, Cisneros RL. Production of experimental ulcerative colitis in gnotobiotic guinea pigs with simplified microflora. Infect Immun 1981;32:225-231.

6. Okayasu I, Hatakeyama S, Yamada M, Ohkusa T, Inagaki Y, Nakaya R. A novel method in the induction of reliable experimental acute and chronic ulcerative colitis in mice. Gastroenterology 1990;98:694-702.

7. Sadlack B, Merz H, Schorle H, Schimpl A, Feller AC, Horak I. Ulcerative colitis-like disease in mice with a disrupted interleukin-2 gene. Cell 1993;75:253-261.

8. Sellon RK, Tonkonogy S, Schultz M, Grenther WB, Balish E, Rennick DM, Sartor RB. Normal enteric flora are necessary for the development of spontaneous colitis and immune system activation in IL-10 deficient mice. Infect Immun 1998;66:5224-5231.

9. Aranda R, Sydora BC, McAllister PL, Binder SW, Yang HY, Targan $S R$, Kronenberg M. Analysis of intestinal lymphocytes in mouse colitis mediated by transfer of $\mathrm{CD}_{4}^{+}, \mathrm{CD} 45 \mathrm{RB}$ high $\mathrm{T}$ cells to SCID recipients. J Immunol 1997; 158:3464-3473.

10. Brandwein SL, McCabe RP, Cong Y, Waites KB, Ridwan BU, Dean PA, Ohkusa, Birkenmeier EH, Sundberg JP, Elson CO. Spontaneously colitic $\mathrm{C} 3 \mathrm{H} / \mathrm{HeJ}$ Bir mice demonstrate selective antibody reactivity to antigens of the enteric bacterial flora. J Immunol 1997;159:44-52.

11. Cong Y, Brandwein SL, McCabe RP, Lazenby A, Birkenmeier EH, Sundberg JP, Elson CO. CD4 ${ }^{+} \mathrm{T}$ cells reactive to enteric bacterial antigens in spontaneously colitic $\mathrm{C} 3 \mathrm{H} / \mathrm{HeJ}$ Bir mice: increased $\mathrm{T}$ helper cell type 1 response and ability to transfer disease. J Exp Med 1998;187:855-864.

12. Rath HC, Herfarth HH, Ikeda JS, Grenther WB, Hamm TE Jr, Balish E, Taurog JD, Hammer RE, Wilson KH, Sartor RB. Normal luminal bacteria, especially Bacteroides species, mediate chronic colitis, 
gastritis, and arthritis in HLA-B27/ human beta 2 microglobulin transgenic rats. J Clin Invest 1996;98:945-953.

13. Hammer RE, Maika SD, Richardson JA, Tang JP, Taurog JD. Spontaneous inflammatory disease in transgenic rats expressing HLA-B27 and human beta $2 \mathrm{~m}$ : an animal model of HLA-B27associated human disorders. Cell 1990;63:1099-1112.

14. Taurog JD, Maika SD, Simmons WA, Breban M, Hammer RE. Susceptibility to inflammatory disease in HLA-B27 transgenic rat lines correlates with the level of B27 expression. J Immunol 1993;150:4168-4178.

15. Taurog JD, Richardson JA, Croft JT, Simmons WA, Zhou M, Fernandez Sueiro JL, Balish E, Hammer RE. The germfree state prevents development of gut and joint inflammatory disease in HLA-B27 transgenic rats. J Exp Med 1994;180:2359-2364.

16. Sutherland L, Singleton J, Sessions J, Hanauer S, Krawitt E, Rankin G, Summers R, Mekhjian $H$, Greenberger $N$, Kelly $M$, Levine J, Thomson A, Alpert E, Prokipchuk E. Double blind, placebo controlled trial of metronidazole in Crohn's disease. Gut 1991;32:1071-1075.

17. Onderdonk $A B$, Bartlett JG. Bacteriological studies of experimental ulcerative colitis. Am J Clin Nutr 1979;32:258-265.

18. Rath HC, Schultz M, Dieleman LA, Li F, Kölbl H, Falk W, Schölmerich J, Sartor RB. Selective vs. broad spectrum antibiotics in the prevention and treatment of experimental colitis in two rodent models (abstr). Gastroenterology 1998;114:A1067.

19. Dieleman LA, Heizer WD. Nutritional issues in inflammatory bowel disease. Gastroenterol Clin North Am 1998;27:435-451.

20. Winslet MC, Andrews H, Allan RN, Keighley MR. Fecal diversion in the management of Crohn's disease of the colon. Dis Colon Rectum 1993;36:757-762.

21. Harper PH, Truelove SC, Lee EC, Kettlewell MG, Jewell DP. Split ileostomy and ileocolos tomy for Crohn's disease of the colon and ulcerative colitis: a 20 year survey. Gut 1983;24:106-113.

22. Brown RG, O'Leary JP, Woodward ER. Hepatic effects of jejunoileal bypass for morbid obesity. Am J Surg 1974;127:53-58.

23. Lichtman SN, Wang J, Sartor RB, Zhang C, Bender DE, Dalldorf FG, Schwab JH. Reactivation of arthritis induced by small bowel bacterial overgrowth in rats: role of cytokines, luminal bacteria and bacterial polymers. Infect Immun 1995;63:2295-2301.

24. Lichtman SN, Sartor RB, Keku J, Schwab JH. Hepatic inflammation in rats with experimental small intestinal bacterial overgrowth. Gastroenterology 1990;98:414-423.

25. Lichtman SN, Keku J, Schwab JH, Sartor RB. Hepatic injury associated with small bowel bacterial overgrowth in rats is prevented by metronidazole and tetracycline. Gastroenterology 1991;100:513-519.

26. Lichtman SN, Keku J, Schwab JH, Sartor RB. Evidence for peptidoglycan absorption in rats with experimental small bowel bacterial overgrowth. Infect Immun 1991;59:555-562.

27. Drenick EJ, Fisler J, Johnson D. Hepatic steatosis after intestinal bypass-prevention and reversal by metronidazole, irrespective of protein-calorie malnutrition. Gastroenterology 1982;82:535-548.

28. Summanen P, Baron EJ, Citron DM, Strong C, Wexler HM, Finegold SM. Wads worth anaerobic bacteriology manual. 5th ed. Belmont, CA: Star, 1993.

29. Lichtman SN, Lacy S, Sartor, RB. Pouchitis following ileal pouchanal anastomosis (IPAA) in rats. Inflamm Bowel Dis 1998;4:187195.

30. Rutgeerts P, Goboes K, Peeters M, Hiele M, Penninckx F, Aerts R, Kerremans $R$, Vantrappen $G$. Effect of faecal stream diversion on recurrence of Crohn's disease in the neoterminal ileum. Lancet 1991;338:771-774

31. Harper PH, Lee EC, Kettlewell MG, Bennett MK, J ewell DP. Role of the faecal stream in the maintenance of Crohn's colitis. Gut 1985;26:279-284.

32. Gump D, Caul E, Eade O, Greenberg H, Kapikian A, MacPherson B, Mitchell P, Parent K, Richmond S, Beeken W. Lymphocytotoxic and microbial antibodies in Crohn's disease and matched controls. Antonie Leeuwanhouk 1981;47:455-464.

33. Helphingstine CJ, Hentges DJ, Campbell BJ, Butt J, Barrett JT. Antibodies detectable by counterimmunoelectrophoresis against Bacteroides antigens in serum of patients with inflammatory bowel disease. J Clin Microbiol 1979;9:373-378.

34. van de Merwe JP, Schroder AM, Wensinck F, Hazenberg MP. The obligate anaerobic faecal flora of patients with Crohn's disease and their first-degree relatives. Scand J Gastroenterol 1988;23:1125-1131.

35. Auer IO, Roder A, Wensinck F, van de Merwe JP, Schmidt $H$. Selected bacterial antibodies in Crohn's disease and ulcerative colitis. Scand J Gastroenterol 1983;18:217-223.

36. Macphers on A, Khoo UY, Forgacs I, Philpott-Howard J, Bjarnason I. Mucosal antibodies in inflammatory bowel disease are directed against intestinal bacteria. Gut 1996;38:365-375.

37. Krook A, Lindstrom B, Kjellander J, Jarnerot G, Bodin L. Relation between concentrations of metronidazole and Bacteroides spp in feces of patients with Crohn's disease and healthy individuals. J Clin Pathol 1981:34:645-650.

38. Garcia-LaFuente A, Antolin M, Guarner F, Crespo E, Salas A, Forcada P, Laguarda M, Gavalda J, Baena JA, Vilaseca J, Malagelada JR. Incrimination of anaerobic bacteria in the induction of experimental colitis. Am J Physiol 1997;193:G10-G15.

39. Turunen UM, Färkkilä MA, Hakala K, Seppälä K, Sivonen A, Ögren $M$, Vuoristo $M$, Valtonen UV, Miettinen TA. Long-term treatment of ulcerative colitis with ciprofloxacin: a prospective double-blind, placebo-controlled study. Gastroenterology 1998;115:10721078.

40. Fuss IJ, Neurath MF, Boirivant M, Klein JS, de la Motte C, Strong SA, Fiocchi C, Strober W. Disparate CD4+ lamina propria (LP) lymphokine secretion profiles in inflammatory bowel disease. Crohn's disease LP cells manifest increased secretion of IFN- $\gamma$, whereas ulcerative colitis LP cells manifest increased secretion interleukin 12 abrogate established experimental colitis in mice. J Exp Med 1995;182:1281-1290.

41. Shull MM, Ormsby I, Kier AB, Pawlowski S, Diebold RJ, Yin M, Allen R, Sidman C, Proetzel G, Calvin D, Annunziata N, Doetschman T. Targeted disruption of the mouse transforming growth factorbeta 1 gene results in multifocal inflammatory disease. Nature 1992;359:693-699.

42. Oberhuber G, Püspök C, Oesterreicher C, Novacek G, Zauner C, Burghuber M, Vogelsang $H$, Pötzi R, Stolte M, Wrba F. Focally enhanced gastritis: a frequent type of gastritis in patients with Crohn's disease. Gastroenterology 1997;112:698-706.

43. Mizoguchi A, Mizoguchi E, Chiba C, Bhan AK. Role of appendix in the development of inflammatory bowel disease in TCR-alpha mutant mice. J Exp Med 1996;184:707-715.

44. Wells $C L$, van de Westerlo EM, J echorek RP, Feltis BA, Wilkins TD, Erlandsen SL. Bacteroides fragilis enterotoxin modulates epithelial permeability and bacterial internalization by HT-29 enterocytes. Gastroenterology 1996;110:1429-1437.

45. Mizoguchi A, Mizoguchi E, Tonegawa S, Bhan AK. Alteration of a polyclonal to an oligoclonal immune response to cecal aerobic bacterial antigens in TCR alpha mutant mice with inflammatory bowel disease. Int Immunol 1996;8:1387-1394.

46. Dianda L, Hanby AM, Wright NA, Sebesteny A, Hayday AC, Owen MJ. T cell receptor-alpha beta-deficient mice fail to develop colitis in the absence of a microbial environment. Am J Pathol 1997;150: 91-97.

47. Brand HS, Maas MA, Bosma A, Van Ketel RJ, Speelman P, Chamuleau RA. Experimental colitis in rats induces low-grade endotoxemia without hepatobiliary abnormalities. Dig Dis Sci 1994;39:1210-1215

48. Neilly PJ, Gardiner KR, Kirk SJ, Jennings G, Anderson NH, Elia M, Rowlands $B J$. Endotoxemia and cytokine production in experimental colitis. BrJ Surg 1995;82:1479-1482. 
49. Gardiner KR, Anders on NH, Rowlands BJ, Barbul A. Colitis and colonic mucosal barrier dysfunction. Gut 1995;37:530-535.

50. Gardiner KR, Halliday MI, Barclay GR, Milne L, Brown D, Stephens $S$, Maxwell RJ, Rowlands BJ. Significance of systemic endotoxemia in inflammatory bowel disease. Gut 1995;36:897-901.

51. Rath HC, Bender DE, Grenther T, Herfarth HH, Holt LC, Taurog JD, Hammer RE, Sartor RB. Normal bacteria stimulate colonic, gastric and systemic inflammation in HLA-B27/ $\beta 2 \mathrm{~m}$ transgenic rats (abstr). Gastroenterology 1995;108:A899.

Received November 26, 1997. Accepted August 10, 1998.

Address for reprint requests to: R. Balfour Sartor, M.D., Division of

Digestive Diseases, Department of Medicine, Microbiology and
Immunology, CB\#7080, Burnett-Womack Building, University of North Carolina at Chapel Hill, Chapel Hill, North Carolina 275997080. Fax: (919) 966-7468.

Supported by U.S. Public Health Service grants DK 34989 and DK 40249, Crohn's and Colitis Foundation of America, Deutsche Morbus Crohn und Colitis Ulcerosa Vereinigung, and Deutsche Forschungsgemeinschaft Ra 671/1-1.

The authors thank Ram Janardaham, Julie Vorobiov, Heidrun Kölbl, Fengling $\mathrm{Li}$, and Rhonda Blitchington for expert technical support; Susie May and Beverly Vought for secretarial expertise; and the Histology and Immunology Cores in the Center for Gastrointestinal Biology and Disease at UNC, Chapel Hill, North Carolina, for assistance. 